\title{
THE MISSING THEORY OF VARIABLE SELECTION IN THE ECONOMIC ANALYSIS OF TORT LAW
}

\begin{abstract}
JAMES M. ANDERSON*
Abstract: $\quad$ The Article argues that the economic analysis of tort law has yet to satisfactorily answer a critical threshold question: which of the many inputs that lead to an accident should be included in a court's liability analysis? As a result of this missing theory, the economic analysis of tort law provides indeterminate prescriptions. The Article shows how three separate areas of the literature can be seen as being about the general problem of which variables to include in the liability test and the tension between short- and long-run optima. The Article proposes an analytical framework - a continuum from short to long run-to understand the problem and show the way in which courts have crafted tort law doctrines to address the issue. Finally, the Article concludes that no satisfactory general theory is possible and that the optimal combination of liability rules will depend upon empirical questions about specific accident contexts.
\end{abstract}

* B.A. Yale University; J.D., Yale Law School. Helpful comments were made by participants in the John M. Olin Program in Law and Economics at which an earlier version of this paper was presented. I would also like to thank Susan Rose-Ackerman, Michelle Anderson, Kate Brownlee, Henry Hansmann, Alvin Klevorick, Jeff Kling, Yair Listokin, Daniel Medwed, Teemu Ruskola, Vera Scanlon, and especially Guido Calabresi, without whom this paper would not be possible. 


\section{CONTENTS}

INTRODUCTION

I. THE UNDERLYING CONCEPTUAL UNITY OF THE LITERATURES ON SEQUENTIAL CARE, ACTIVITY LEVEL VS. LEVEL OF CARE, AND CAUSATION ........................ 6

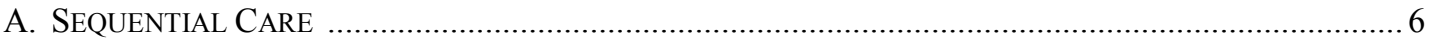

B. Activity LeVEl vs. LeVel of CARe, or, Should the Court Consider How Often the

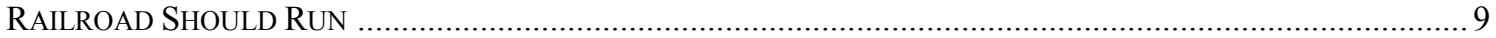

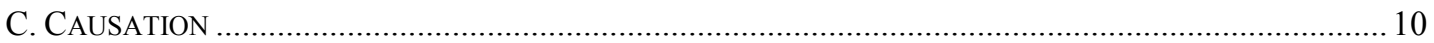

II. THE INDETERMINACY OF THE CONVENTIONAL ECONOMIC ANALYSIS OF

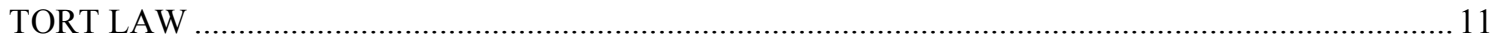

III. THE SHORT TO LONG RUN ANALYTICAL FRAMEWORK AND TORT

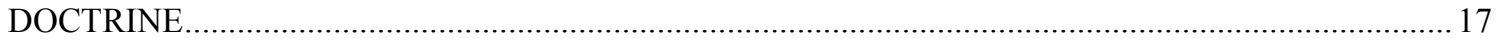

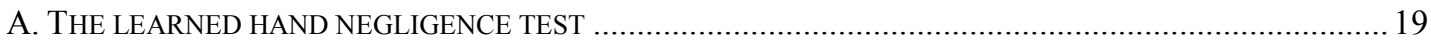

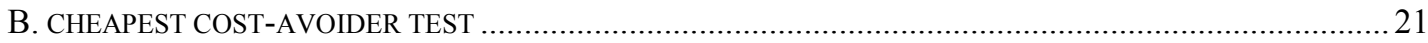

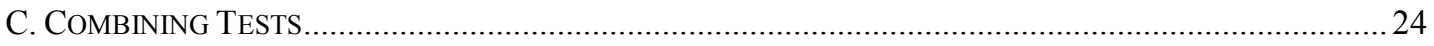

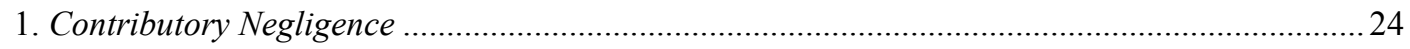

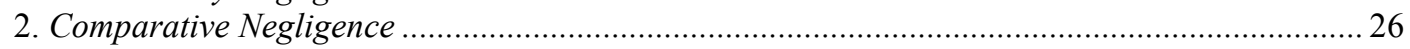

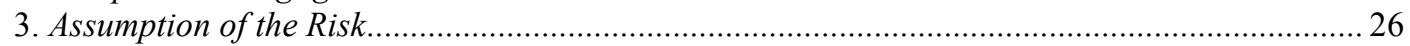

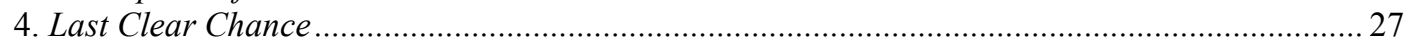

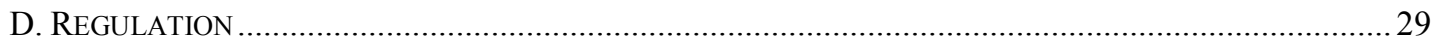

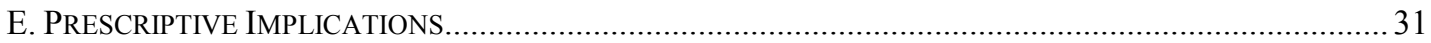

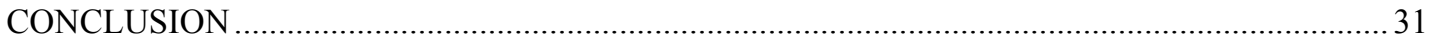




\section{INTRODUCTION}

This Article argues that the economic analysis of tort law has yet to satisfactorily answer a critical threshold question: which of the many inputs that lead to an accident should be included in a court's liability analysis? As a result of this missing theory, the economic analysis of tort law provides indeterminate prescriptions. I will propose an analytical framework to understand the problem and the way in which tort law grapples with the tension between long run and short run optima. Finally, I will conclude that no satisfactory general theory is possible and that the optimal combination of liability rules will depend upon empirical questions about the specific accident contexts.

Consider, for example, Judge Learned Hand's famous opinion in United States $v$. Carroll Towing. ${ }^{1}$ After a tugboat operator negligently rearranged the lines securing a group of barges on the Hudson River, one of the flour-laden barges came detached. It floated up the Hudson River on the south wind and tide, collided with the propeller of another ship, and sprang a slow leak. It eventually capsized and sank. One of the questions Hand faced was whether the owner of a barge owed a duty to keep a bargee (watchman) while the barge was moored to prevent the barge from coming loose. Hand famously attempted to formalize his logic into a mathematical formula: B $<$ PL. In Hand's formulation, B, the proper burden of care, was defined by the probability of harm, $(\mathrm{P})$, multiplied by the cost of the loss that would result in (L). If a measure to prevent the harm cost more than the cost of the harm multiplied by the probability of the harm, it was not efficient and a defendant should not be considered negligent. If, on the other hand, the accident-reducing measure cost less than the probability of harm multiplied by the cost of the harm, it was efficient to undertake the precaution and the defendant should be found negligent for failing to do so. In this way, Judge Hand attempted to provide an economic metric and conceptual rigor to the analysis of the accident prevention methods - the duty of care-required. Hand's explicitly algebraic reasoning has been cited as an important milestone in the economic analysis of tort law. ${ }^{2}$

${ }^{1} 159$ F.2d 169 (2d Cir. 1947).

${ }^{2}$ William M. LANDES \& Richard A. Posner, THE ECONOMic Structure OF TORT LAW 85 (1987); John Prather Brown, Toward an Economic Theory of Liability, 2 J. LEGAL STUD. 323, 33135 (1973); Mark Grady, Untaken Precautions, 18 J. LEGAL STUD. 139, 147 (1989) (citing Carroll Towing as "the centerpiece of the conventional economic theory of negligence"). Indeed, in an effort to give law and economics more historical resonance, "[a]ny judge who was at all selfconscious about what he was doing was canonized" by practitioners of the new law and economics. SusAn Rose-Ackerman, RethinkING the Progressive Agenda 22 (1992) (citing use of Learned Hand's portrait as the frontispiece and Hand's economic opinion in Carroll Towing 
But why was the issue limited only to the cost of putting a watchman on board the barge at night? Why did the analysis not end with a finding that the tugboat negligently disconnected the barge's stays? Why not also consider the cost of designing barges so that they do not spring leaks after collisions? Why not also consider whether the other vessel could have avoided the collision with the runaway barge? Could not the accident have been prevented in many other ways?

More generally, which accident-reducing inputs should a court take as fixed and which as variable in addressing whether the putative injurer or victim are negligent? Since most accident risk can be reduced (or increased) in a nearly infinite number of ways, this question is central to tort law. Consider, for example, an accident between an automobile and a pedestrian. This can be seen as a function of the skill of the driver, and his selection of automobile, tires, and brakes, to name only a few of the potential inputs. The pedestrian inputs include, inter alia, precautionary measures and the frequency of his excursions to the location of the accident. Other variables include the quality and design of the roadway, road surface, and sidewalk. A change in any of these inputs might affect the net costs of accidents. Which should a court consider? Surprisingly, there has been relatively little effort to address the general issue of accident input inclusion in the literature. ${ }^{3}$

This issue is complicated by the way in which tort law faces competing and sometimes irreconcilable goals to optimize in the short run and in the long run. A liability test that includes every accident-reducing input might be efficient in the long run but will provide little incentive for subsequent actors to minimize accident costs once negligence has occurred. To examine another famous example, suppose our society includes railroads that emit sparks and farmers with flammable crops. ${ }^{4}$ Further suppose that the long-run efficient solution is for railroads to purchase special no-spark engines. If the railroad fails to use no-spark engines, the farmer can efficiently minimize damages by leaving a gap between the railroad and the flammable crops. Finally, suppose that the railroad has not

as epigram of Richard Posner, TORT LAW: CASES AND ECONOMIC ANALYSIS (1982)). Stephen Gilles recently questioned the assumption that Hand's formulation was an attempt at ensuring efficient resource allocation. Stephen G. Gilles, On Determining Negligence: Hand Formula Balancing, the Reasonable Person Standard, and the Jury, 54 VAND. L. REV. 813, 849 (2001).

${ }^{3}$ Giuseppe Dari-Mattiacci squarely addresses the general issue of which variable inputs should be considered in the negligence test, but answers the question only in terms of administrative cost reduction. Giuseppe Dari-Mattiacci, On the Optimal Scope of Negligence (George Mason School of Law, Law and Economics Working Paper Series (2004)). See infra notes 6-24 and accompanying text for discussion of literature.

${ }^{4}$ A.C. Pigou, The Economics of Welfare 134, 192 (1932). See Rene Demogue, Fault, Risk, and Apportionment of Loss in Responsibility, 15 ILL. L. REV. 369 (1921). Rather than use a tort system, Pigou proposed a tax to force the accident-causing actors to internalize these costs. 
purchased no-spark engines. If the court considers this first input in the liability test, the farmer will have no incentive to leave a gap or take any efforts to minimize damages since she knows that the railroad will be found liable for the damages as a result of its negligence. On the other hand, if the court takes the railroad's failure to purchase no-spark engines as given, and outside the scope of the liability analysis, the farmer will have the proper incentives to take care but the railroad will not.

The central problem this Article addresses is the way courts determine which accident-reducing inputs are taken as given and which are considered potentially negligent choices by the parties in determining liability. The Article proposes a framework for considering this problem: placing the range of accidentreducing inputs along a rough temporal continuum from long before the accident to the moment the loss becomes irreversible. In applying an economic test to determine liability, an analyst (or court) chooses a certain subset of these inputs to examine. So, for example, a long-run test for negligence would consider more inputs as variable, and more actions as potentially negligent. In contrast, a shorter-run test takes more inputs as given and outside the scope of the negligence analysis.

In the first section I explain the application of the idea of differing shortand long-run optima in the economic analysis of tort law and briefly review the literature. I show that three different areas in the literature of the economic analysis of tort law can be understood as part of the general problem of determining which variables a court includes in a liability test. In the second section, I explain how the conventional economic models of tort law yield indeterminate predictions as to which variables a court should consider and how the variable choice will determine the outcome of the liability test. I show that, absent additional empirical information, economic theory cannot tell us a priori what the best rule is in a particular accident setting. In the third section, I propose a descriptive analytic framework for understanding the issue and show how tort law doctrines map onto this framework. Finally, I conclude that the optimal choice of variables will depend on specific empirical questions about short- and long-run accident-affecting technologies and the structure of the relevant markets. This suggests opportunities for further research.

\section{THE UNDERLYING CONCEPTUAL UNITY OF THE LITERATURES ON SEquential Care, Activity Level vs. Level of CARE, AND CAUSATION}

The economics of tort law literature has considered the issue of what inputs a court should consider as part of the liability test in three specific areas: 
sequential care, standard of care vs. activity level, and causation. ${ }^{5}$ Each of these areas can be seen as a specific instance of the general problem of determining which inputs a court should consider given and which variable. Unfortunately, the three areas rarely reference each other or identify the general issue of including and excluding accident inputs.

\section{A. Sequential Care}

Commentators have examined the problem of strategic behavior when injurer and victim choose levels of care sequentially. ${ }^{6}$ Consider again the example of the spark-emitting railroad next to the farmer with flammable crops. The net social cost of the railroad operation may be substantially higher than the private cost of the railroad because the overall social cost must include the cost of the fires generated by the sparks. As a result of this divergence, the railroad operator's incentives may be distorted by this externality. ${ }^{7}$ On the traditional law and economic account, the tort system can induce the railroad and the farmer to take the efficient standards of care to minimize the social cost of fires by the use of a negligence test with a defense of contributory negligence or strict liability with a defense of contributory negligence. The railroad will take the efficient amount of care to avoid being found negligent, let us assume by utilizing a spark

\footnotetext{
${ }^{5} \mathrm{I}$ omit a fourth way this issue is sometimes avoided in the literature. As a matter of pure static law and economics, the issue never arises because no party is ever negligent. If one assumes omniscient courts, the negligence test could incorporate every efficient accident-reducing method. Knowing that it will be found negligent if it fails to undertake the efficient measure, whichever party acts first will always take the efficient actions. Accordingly it will never be found negligent. In order to avoid liability, the second party will do the same. This argument can be extended indefinitely from the longest-run actors to the actions of the victim immediately before the accident. On this logic, only efficient accidents will occur. STEVEN SHAVELL, ECONOMIC ANALYsis of ACCIDENT LaW 83-84 (1987); Susan Rose-Ackerman, The Simple Economics of Tort Law: An Organizing Framework, 2 EUR. J. POL. ECON 91, 96 (1986).

${ }^{6}$ Steven Shavell, Torts in which Victim and Injurer Act Sequentially, 26 J. LEGAL STUD. 589 (1983); Steven Shavell, Strict Liability vs. Negligence, 9 J. LEGAL STUD. 1 (1980); Donald Wittman, Optimal Pricing of Sequential Inputs: Last Clear Chance, Mitigation of Damages, and Related Doctrines in the Law, 10 J. Legal STUD 1965 (1981); Lewis A. Kornhauser \& Richard L. Revesz, Sequential Decisions by a Single Tortfeasor, 20 J. LEGAL STUD. 363 (1991); William M. Landes \& Richard A. Posner, Joint and Multiple Tortfeasors: An Economic Analysis, 9 J. LEGAL STUD. 517 (1980); Mark F. Grady, Control of Strategic Behavior: Railroad Sparks and the Farmer, 17 J. LEGAL STUD. 15, 16 (1988).

${ }^{7}$ PIGOU, supra note 4. In the landmark The Problem of Social Cost, Ronald Coase took Pigou's example of the railroad and the farmer and noted that that it was the incompatibility of the activities undertaken by the injurer and the victim that caused the problem of social cost and not merely the activity of the injurer. R.H. Coase, The Problem of Social Cost, 3 J. LAW \& ECON. 1 (1960).
} 
arrestor. Since the farmer will bear the residual costs, she will take whatever other steps are economically efficient to minimize costs. ${ }^{8}$

But suppose the spark-emitting railroad ignores the efficiency of a spark arrestor and does without one. ${ }^{9}$ The farmer, knowing that the railroad will be spewing sparks, ${ }^{10}$ might be held contributorily negligent if he does not take elaborate, but cost-justified precautions to prevent the sparking railroad from igniting his crops. ${ }^{11}$ In this way, the railroad could make the farmer pay for the costs of accident prevention. The conventional law and economic description of this situation is that the farmer should not be found contributorily negligent so as to allow the cost to be shifted on to him, ${ }^{12}$ unless the "danger posed by the injurer's activity is very conspicuous," $" 13$ in which case the victim's failure to avoid the accident might be found contributorily negligent. ${ }^{14}$ This solution is problematic because it encourages the railroad conspicuously to emit sparks.

${ }^{8}$ John Prather Brown, Toward an Economic Theory of Liability, 2 J. LEGAL STUD. 323 (1973).

${ }^{9}$ See Grady, supra note 6 at 16 (noting that "the question is whether each side must take additional precautions once he knows (or has reason to know) that the other party is negligent"); Steven Shavell, Torts in which Victim and Injurer Act Sequentially, 26 J. LEGAL STUD. 589, 590 (1983) ("What will be of special interest about the working of liability rules in the model is twofold - that the party who acts second behaves in response to the party who acts first, and that the party who acts first will take the response of the party who acts second into account.").

${ }^{10}$ This example assumes that the farmer knows that the railroad will be spewing sparks and plants or stacks his crops accordingly. If the farmer does not know that the railroad would be spewing sparks, this example becomes one of simultaneous care rather than sequential care.

${ }^{11}$ See e.g, LeRoy Fibre Co v. Chicago, Milwaukee \& St. Paul Ry., 232 U.S. 340, 352 (1914) ("as a general proposition people are entitled to assume that their neighbors will conform to the law . . . and therefore... are entitled to assume that their neighbors will not be negligent") (Holmes, J. concurring). In LeRoy Fibre the issue was whether flax that had been stacked 85 feet away from the train tracks was negligently close. LANDES \& POSNER, supra note 2 at 89 ("The accident no doubt could have been prevented by removing the flax to a greater distance from the tracks, but if this fact made the owner of the flax contributorily negligent, the railroad would have an incentive to spew sparks and cinders with abandon in order to induce the owner to remove the flax to as great a distance as possible, thus minimizing the railroad's own costs of preventing damage to the crops.").

${ }^{12} I d$. at 90.

${ }^{13} \mathrm{Id}$. at 90 (noting analogue to last clear chance doctrine).

${ }^{14}$ Landes and Posner argue that "the temptation of potential injurers deliberately to create palpable dangers in order to induce potential victims to take excessive precautions is held in check by the fact that contributory negligence is not a defense to intentional or reckless conduct." Id. at 90. Mark Grady suggests that the conventional account is problematic, recognizes that negligence test includes a built-in time structure, and proposes that courts require victims to take compensatory precautions only in categories of accidents in which there is unlikely to be the opportunity for strategic behavior. Grady, supra note 6 at 41 . He suggests that the railroad fire situation, often used as paradigmatic in law and economic accounts, was actually uniquely suited to strategic behavior and that other accident situations were not. Id. at 41 . 
Mark Grady notes that the elaborate literature, abounding with "cases, models, equations and so forth," essentially ignores "the one question that emerged from [John Prather] Brown's analysis as central: must the one side take additional precautions when it knows the other has failed in its duty?"15 Grady suggests that the common law solves this problem by applying different rules to different time periods to avoid this problem. So, for example, he distinguishes contributory negligence in what he calls the preparation period, that is, assuming that the other party was taking proper care, from contributory negligence in the reaction period, when it is clear to both parties that the first party has been negligent. He argues that courts sometimes control strategic behavior by making the reaction party rule depend on whether the other party's negligence was deliberate. ${ }^{16}$ So that in the case of the spark-emitting steam engine, the farmer's contributory negligence would not bar recovery, because the absence of a spark arrestor is presumably deliberately strategic. ${ }^{17}$

For our purposes, this problem of sequential behavior and the resulting strategic behavior can also be understood as a specific case of whether the court wants to induce the long-run optimal solution, by, for example, holding the railroad liable for the spark-emitting engine, or the shorter-run optimal solution which takes the railroad's sparks as a given and requires the farmer to take precautionary measures. Either the court can provide incentives for the short-run optimum (ignoring the negligence of the railroad) or the long-run optimum (and erode incentives for the farmer to take remedial action).

\section{B. Activity Level vs. Level of Care, or, Should the Court Consider How Often the Railroad Should Run?}

In a different line of articles, other commentators point out that the solution reached by the negligence test might be inefficient if it were socially optimal to reduce the amount of the activity rather than just affect the way in which the activity is carried out. ${ }^{18}$ Generally, under a negligence rule, an injurer

\footnotetext{
${ }^{15}$ Grady, supra note 6 at 17 . Grady is referring to Brown, supra note 8. See also Susan Rose-Ackerman: Entitlement and Efficiency in Tort Law, 18 J. LEG. STUD. 25, 26 (noting that in some areas the law gives stronger entitlement to careless victim than careful one because law requires reimbursement for all consequential damages but not for the victim's prevention costs).

${ }^{16}$ Grady, supra note 6 at 25 .

${ }^{17}$ Section III of this Article can be seen, in part, as an extension of this work. Rather than identify three time periods for accident reducing inputs, this Article proposes a continuum on which accident-affecting inputs lie. As explained below, the Article also recognizes that the essential structure of both the activity-level vs. level of care and the limit of proximate cause issues are the same as this sequential care issue.

${ }^{18}$ Steven Shavell, Strict Liability vs. Negligence, 9 J. LEG. STUD. 1 (1980); LANDES \& POSNER, supra note 2 at 102; A. Mitchell Polinsky, Strict Liability vs. Negligence in a Market Setting, 70
} 
has only to exercise due care to avoid the possibility of liability rather than consider the possibility of reducing the amount of activity he undertakes. So if it would be efficient to eliminate railroading or farming, a negligence test would not result in the efficient result, because negligence usually looks to the level of care and not to the level of the activity itself. Steven Shavell, for example, discusses including activity levels in the standard of due care and points out that under a negligence standard, parties will only take sufficient care in those dimensions of due care that the court examines. ${ }^{19}$ More recently, Giuseppe Dari-Mattiacci has proposed a theory of determining which factors to include in the negligence test and which to exclude as activity levels based on the administrative costs of courts making these determinations ex post. $^{20}$

Again, however, the issue of whether an input is an activity level (and therefore taken as a given in most analyses) or constitutes level of care (and therefore included in the analysis) is a question of what collection of inputs the court will consider variable and which it will take as given. Will the court see a longer-run optimum (including activity levels) or a shorter-run optimum (excluding activity levels)?

Like the problem of sequential care discussed above, this issue also has a temporal component that can lead to strategic behavior. If a railroad knows that

AMERICAN ECONOMIC ASSOCIATION 363 (1980); Susan Rose-Ackerman, The Simple Economics of Tort Law: An Organizing Framework, 2 EUR. J. POL. ECON. 91, 97 (1986) ("If accident probabilities depend, in part, on the number of miles driven or walked, then a negligence standard based only on speed will be inefficient."); Alan J. Meese, The Externality of Victim Care 9-10 (Social Science Research Network Electronic Paper Collection, available at http://papers.ssrn.com/paper.taf?abstract_id=237992) ("Theoretically, courts could include within their examination of the injurer's care an inquiry into whether it was reasonable to engage in the activity in question."); see also Michelle White and Donald Wittman, Optimal Spatial Location Under Pollution: Liability Rules and Zoning, 10 J. Legal STUD. 249 (1981), for a discussion of different short and long run solutions in pollution control.

${ }^{19}$ Steven Shavell, ECONOMic Analysis of AcCident LaW 9, 26 (1987) and Steven Shavell, Strict Liability Versus Negligence, 9 J. LEGAL StUD. 1, 8, 22 (1980). Shavell notes the information cost difficulties of a court incorporating activity levels into the negligence analysis. Id. at 23 .

${ }^{20}$ Giuseppe Dari-Mattiacci, On the Optimal Scope of Negligence (George Mason School of Law, Law and Economics Working Paper Series) (2004). Dari-Mattiacci criticizes the conventional assumption that "level of care" and "activity level" have some independent natural meaning that is exogenous to the model. Instead he provides a theory as to what kinds of precautionary actions should be considered in the negligence analysis based on the administrative and informational costs of a court determining optimal accident reduction efforts ex post. DariMattiacci is right to criticize the procrustean division of means of accident reduction into level of care vs. activity level. This article proposes a more nuanced analytical continuum (short run to long run) in lieu of the simply distinction between standard of care and activity level. DariMattiacci does not consider the possibilities for strategic behavior in his analysis of what inputs should be considered in the negligence calculus. See note 38 infra for further discussion of DariMattiacci's analysis. 
the number of trains it runs is never considered in the liability analysis, it will have no incentive to consider the costs of the fires that come from those trains, as long as it is not negligent. In this way, it can pass the cost of precautions onto the farmer. Conversely, if the farmer knows that the railroad will be found negligent for the number of trains it operated, the farmer has no incentive to take remedial care. Structurally, this problem is identical to that of the strategic behavior considered above. It can also be considered a specific case of the general problem of how the court should decide which inputs to consider fixed and which variable. $^{21}$

\section{Causation}

In yet a third line of articles, commentators have examined the use of the concept of proximate causation in limiting liability. ${ }^{22}$ These commentators have focused on developing a theory of when and how recovery should be limited by a court finding that a particular act of negligence was not the proximate cause of an accident. So, for example, Mark Grady examines Pittsburg Reduction Co. v. Horton, ${ }^{23}$ where the defendant company left explosive blasting caps on a site. The blasting caps were picked up by a boy, taken home, and shown to his mother. The boy then traded them with another boy who was injured. The question was whether the intervening negligence of the mother broke the causal linkage between the negligence of the defendant company and the injury of the boy.

Yet again, the question of which inputs the court should take as variable and which it should consider as given arises. And again, the problem of eroding the incentives for the initially negligent party arises. As Mark Grady explains it, "The purpose of the direct-consequences doctrine is to cut off the liability of the person responsible for the original cause in circumstances when it is desirable to

${ }^{21}$ If everyone simply takes a limitation on liability for granted, a first actor may be able effectively to pass the cost of precautionary measures on to subsequent actors. In a state without dram shop liability, for example, the bar owner may not take efficient measures to reduce alcoholinduced accidents. Similarly, a city may not redesign a dangerous intersection if it is immune. In both instances, the first actor (the bar owner or city) will be able to avoid bearing any of the costs of the accidents and has no incentive to take efficient remedial measures. It seems odd to speak of this lack of action by the bar owner or city as "strategic," but the situation is analytically similar to that of the railroad owner who knows that the number of trains that he runs is not included in the liability analysis.

22 Steven Shavell, An Analysis of Causation and the Scope of Liability in the Law of Torts, $9 \mathrm{~J}$. Legal Stud. 463 (1980); Mark F. Grady, Proximate Cause and the Law of Negligence, 69 IowA L. REV. 363 (1984); William M. Landes \& Richard A. Posner, Causation in Tort Law: An Economic Approach, 12 J. LeGAL STUD. 109 (1983); see also Guido Calabresi, Concerning Cause and the Law of Torts: An Essay for Harry Kalven, Jr., 43 U. CHI. L. REV. 69 (1975).

${ }^{23} 87$ Ark. 576, 113 S.W 647 (1908). 
prevent an erosion of the incentive to take precaution on the part of the person who is responsible for the intervening cause." 24

All three of these areas in the economic analysis of tort law-sequential actors, activity level vs. standard of care, and the reach of causation - are closely related. Each can be seen as aspects of the same problem: trying to provide the correct long-run incentives, without eroding shorter-run incentives. Yet the literatures on each issue seldom address one another or acknowledge the conceptual unity of the problem. The general problem is that we want tort law to induce a social optimum under multiple sets of constraints: both when the existence of the first party's negligence is still a variable and also once it has already occurred and is taken as a given. In this first section I introduced the problem of varying short- and long-run solutions of the social optimum and explained how three areas of the economics of tort law literature can be understood as being about this same general problem.

\section{THE INDETERMINACY OF CONVENTIONAL ECONOMIC ANALYSIS OF TORT LAW}

In this section, I explain that the conventional economic analysis of tort law lacks a satisfactory theory of which accident variables a court should consider in its test or combination of tests. As a result, the economic analysis of tort law can be indeterminate in many situations. ${ }^{25}$

In an ideal world, the courts would not face the tension between the short run and the long run because parties would never be negligent and courts would be omniscient. In such a world, courts (or other institutions) would determine optimal solutions, carefully considering the accident cost reduction probabilities of every possible action by every possible party. An all-inclusive Learned Hand negligence rule, incorporating every possible aspect of behavior, could induce parties to conform to the optimum. Parties would always take this efficient amount of accident precaution. Since no party would ever be negligent, courts would not have to address any second-best solutions. ${ }^{26}$

${ }^{24}$ Grady, supra note 22 at 416.

25 See Eric A. Posner, Economic Analysis of Contract Law after Three Decades: Success or Failure? 112 YALE L.J. 829, 834 (2003) (discussing indeterminacy of economic analysis of contract law); see also Ian Ayers, Valuing Modern Contract Scholarship 112 YALE L.J. 881, 884 n.17 (2003) (defending utility of economic analysis of law even if it yields somewhat indeterminate predictions); LOUIS KAPLOW \& STEVEN SHAVELL, FAIRNESS VERSUS WELFARE, 457-58 (2002) ("Implicit in the notion that this uncertainty (so-called indeterminacy) constitutes a criticism of welfare economics is that easily answered questions -which necessarily ignore relevant, although complicated, features of reality - are somehow better to consider").

${ }^{26}$ STEVEN SHAVELL, ECONOMIC ANALYSIS OF ACCIDENT LAW 83-84 (1987) (noting that under pure economic theory, no party would be negligent). 
But, as behavioral legal economists, among others, have noted, we often live in a world of second-, third-, or fourth-best options. ${ }^{27}$ Sub-optimal behavior and courts with limited information are the rule. Human beings are particularly poor at estimating and thinking about the likelihood of improbable events - such as accidents. ${ }^{28}$ We tend to underestimate the likelihood of a low-probability event until one occurs. At that point, we overestimate the likelihood of a similar event's recurrence. $^{29}$ Because of errors of this sort and the commonness of negligence, the courts do not usually find the unconstrained optimum and seek to hold parties to that standard. Once sub-optimal behavior occurs, the constraints on the social optimization problem change and there is a new most efficient solution. ${ }^{30}$ Yet how does tort law take into account the new solution without undermining the long-term optimum?

Before explaining how the tort system adjusts to this situation, I will more thoroughly discuss what is meant by short and long run. The conventional way of analyzing accident cost reduction as exemplified by William Landes and Richard Posner in THE ECONOMIC STRUCTURE OF TORT LAW ${ }^{31}$ makes a fairly gross distinction between short run and long run by dividing the activities a party can take to affect accident costs into two categories, the amount of the activity and the level of care engaged in while undertaking this activity.

On the standard view, one can then separate activities in which the level of care is the chief determinant of the cost of accidents from activities in which the

${ }^{27}$ See Christine Jolls, Cass R. Sunstein, Richard Thaler, A Behavioral Approach to Law and Economics, 50 STAN. L. REV. 1471, 1518 (1998) (discussing application of bounded rationality to law and economics).

${ }^{28}$ See Howard Kunreuther, The Economics of Protection Against Low Probability Events, in DECISION MAKING: AN INTERDISCIPLINARY INQUIRY 195, 209 (Gerardo R. Ungson \& Daniel N. Braustein eds., 1982).

${ }^{29}$ See Jolls, Sunstein \& Thaler, supra note 27 at 1518-1521 (discussing application of the availability heuristic to environmental regulation); JERRY L MASHAW \& DAVID HARFST, THE STRUGGLE FOR AUTO SAFETY 141-46 (1990) (discussing regulation of school buses in wake of highly publicized school bus accidents).

${ }_{30}$ The inconsistent nature of the tort system at providing deterrence (because it relies on private parties bringing litigation) further complicates the optimization problem. See John C. P. Goldberg, Twentieth Century Tort Theory, 91 GEO. L. J. 513, 554 (2003) (noting that as a result of this problem, "economic accounts therefore fail to offer a compelling account of the deep structure of tort law."); Mark Geistfield \& Susan Rose-Ackerman, The Divergence Between the Social and Private Incentives to Sue, 16 J. LegAL STUD. 483 (1988).

${ }^{31}$ William M. LANDES \& Richard A. Posner, The ECONOMIC Structure of TORT LAW (1987). Posner's jurisprudence has also been influenced by this model. Indiana Harbor Belt R. Co. v. American Cyanamid Co. 916 F.2d 1174 (7th Cir. 1990) (rejecting application of strict liability for transportation of hazardous chemicals). See also STEVEN SHAVELL, ECONOMIC ANALYSIS OF ACCIDENT LAW 25 (1987) (explaining that "failing of the negligence rule under discussion can be regarded as resulting from an implicit assumption that the standard of behavior used to determine negligence is defined only in terms of care"). 
activity level is important. ${ }^{32}$ Landes and Posner argue that strict liability is best for activities in which the cost of accidents is relatively inelastic with respect to victim precaution and relatively elastic with respect to injurer level of activity (as opposed to standard of care), whereas a negligence regime is best for activities in which the cost of accidents is relatively elastic with respect to victim standard of care and relatively inelastic with respect to the level of the activity of the injurer. ${ }^{33}$ Blasting, for example, is cited as a good activity for the application of strict liability because victims can do little to take care to reduce accident costs and there are substitutes for the activity. ${ }^{34}$ This view however, fails to consider the richness of both the injurer's and the victim's possibilities to affect accident costs and the resulting multitude of options for the courts in fashioning liability rules. The conceptual simplicity and ease in modeling afforded by the dichotomy comes at a cost in descriptive subtlety.

Any injurer or victim can take a wide variety of measures to reduce accidents. This variety can be analyzed by using the two conventional categories of accident cost reduction: (1) reducing the amount of the activity; and (2) increasing the level of care taken. An example of these methods of accident reduction can be seen in driver-pedestrian accidents. A driver can reduce accidents by driving less, or by driving more carefully. These two variables correspond with the conventional two categories of accident cost analysis used in the literature. But a driver might also affect accident costs by driving a different route to work or by buying a more or less dangerous (for himself or others) car or by buying new tires or taking a safe driving course. ${ }^{35}$ A pedestrian's opportunities to reduce accident costs also exceed the two categories. She could walk less, or walk more carefully. But she could also walk in a different place, wear different shoes, wear reflective clothing, or develop her reflexes so she can better leap out of a car's way. Other actors also affect the cost of accidents. The local government could build wider sidewalks, more traffic lights, or better subsidize mass transit.

${ }^{32}$ See also Shavell, supra note 5 at 5 (injurers and victims will each have (at least potentially) two kinds of decisions to make: a decision whether, or how much, to engage in a particular activity; and a decision over the degree of care to exercise when engaging in an activity.); Id. at 26

${ }^{33}$ LANDES \& POSNER, supra note 2 at 66-70.

${ }^{34}$ LANDES \& POSNER, supra note 2 at 113; see also Indian Harbor Belt Railroad Company v. American Cyanamid Company, 916 F.2d 1174, 1177-78 (1990) (Posner, J.) (discussing history of strict liability and application to blasting; rejecting application of strict liability to shipping hazardous chemical).

${ }^{35}$ Many have noted the arbitrariness of the level of precaution and level of activity categories and their descriptive inadequacy. See, e.g., Dari-Mariacci, supra note 3 at 2 ("In fact, motorists can prevent accidents not only by moderating their speed, but also by controlling the good functioning of their brakes, correctly using the rearview mirror, avoiding driving when tired, driving their car less often, and so forth."); Stephen G. Gilles, Rule-Based Negligence and the Regulation of Activity Levels, 21 J. LEGAL STUD. 319 (1992). 
It is possible to shoehorn all of these accident cost inputs into the two categories mentioned above, and this certainly makes for ease in modeling. It is easy to reconceptualize driving a different, safer way to work, for example, as a reduction of the activity level if we define the activity as driving by a particular street. But such redefinition ignores the substantial differences in the way the tort system treats different methods of accident reduction. ${ }^{36}$

Dari-Mariacci recently formulated this problem: "Until now, economic analyses have disregarded the multidimensional nature of precaution and thus have not studied the optimal composition of the bundle of precautionary measures, that, if untaken, amount to negligent behavior." ${ }^{37}$ As he observes, "any precautionary measure defined as care ... can be reinterpreted as a level of activity and vice-versa." 38

As a result of this missing theory, the economic analysis of tort law can be indeterminate, even when applied to relatively simple hypotheticals. Should a court consider the choice of automobile in determining whether or not a driver was negligent? ${ }^{39}$ The conventional economic model of tort law provides no

${ }^{36}$ The conventional activity-level/level of care dichotomy also obscures the sequential nature of accident cost reduction inputs. So, for example, the local government builds a road and sidewalk of a particular size and shape. The driver purchases a particular automobile of a standard type. The pedestrian decides to walk to work instead of taking the bus. All of these accident inputs occur sequentially, and subsequent actors often act with knowledge of the prior actors' decisions. The driver and the pedestrian know the size and shape of the road and sidewalks. Pedestrians know the general qualities of automobiles. This raises the concerns in the sequential actor literature discussed above. See text accompanying notes 5 -17 supra.

${ }^{37}$ Dari-Mariacci, supra note 3 at 2 . He helpfully traces the intellectual history of the way in which this question, which was recognized by the early scholars of the law and economics of tort law, became obscured. Id. at 4-5.

${ }^{38}$ Dari-Mariacci, supra note 3 at 5 ("For example, riding a bike on a dangerous road may be seen as a lack of care, if emphasis is put on the fact that the cyclist could have ridden on a safer trail. However, one could interpret this form of precaution as the frequency of the activity 'riding on dangerous paths,' which is a different activity from 'riding on safe paths'"); see Peter A. Diamond, Single Activity Accidents, 3 J. LEGAL STUD. 107, 110 (1974) (noting distinction between activity levels and standard of care "somewhat artificial"). Unfortunately, Dari-Mariacci's solution is extremely abstract. He proposed an economic theory of the scope of negligence - a theory as to which variables a court should consider in the negligence analysis and which should be considered outside the scope of the negligence analysis. Id. at 5. His model is based on minimizing the sum of accident costs and administrative costs. In some respects, his proposal is very similar to Calabresi's proposal to place liability on the cheapest cost avoider. Dari-Matiacci at 15 ("Thus, the residual bearer should be optimally chosen in order to minimize three different costs: the total accident costs, the information costs of verifying either the injurer's or the victim's behavior, and the compensation costs that arise when the injurer is the residual bearer."); see id. at 20 (citing GuIDO CALABRESI, THE COSTS OF ACCIDENTS (1970)).

39 Another way of asking this question is to ask whether the choice of car should be considered a proximate cause of an accident. See supra text accompanying notes 18 - 24 (explaining similarity in scope of negligence and causation inquiries). 
answer to this question. ${ }^{40}$ Should the choice of automobile be treated as an activity level (and taken as a given) or a component of the standard of care? The answer to this question may drive the result of the liability test. The dangerous car driver is more likely to be found liable if a choice of automobile can be considered negligent.

Indeed, the answer depends upon context- and industry- specific questions: Would failing to incorporate this variable encourage drivers to purchase unsafe automobiles? ? $^{41}$ If so, how many more accidents would result? Would potentially finding drivers negligent for the choice of automobile lead pedestrians to take fewer precautions? Are there other accident-affecting variables that the decision to include or exclude the choice of automobile would affect? These are all questions that could potentially be empirically addressed but are not even usually identified as relevant by the conventional law and economic models.

The indeterminacy also surfaces occasionally in the literature. So, for example, In Strict Liability: A Comment, ${ }^{42}$ Richard Posner criticizes Calabresi's advocacy of strict liability.

For example, suppose that people are frequently injured because the blade of their rotary mower strikes a stone and that these accidents could be prevented at least cost by the operator of the mower, who need only remove the stones in his path. Calabresi suggests that the manufacturer of the mower might nonetheless be liable under his approach. The injury is an expectable one and the manufacturer is in a better position than the user to figure out how to minimize the relevant costs.

To impose liability on the manufacturer in this case, however, is inefficient: it eliminates the incentive of the operator to adopt a more economical method of preventing the injury. One

\footnotetext{
${ }^{40}$ This critique is somewhat similar to that of Eric Posner's recent critique of the law and economics of contract law. Eric A. Posner, Economic Analysis of Contract Law After Three Decades: Success or Failure?, 112 YALE L.J. 829, 838 ("[T] he models taken together are probably indeterminate. To generate predictions, one would need a vast amount of information about the characteristics of the parties and the transactions... Yet no one has attempted to collect this information, and it is difficult to imagine how this task could be accomplished"). As explained below, I am more optimistic about the possibility of gathering the relevant information in specific accident contexts.

${ }^{41}$ For many years, there were no requirements for pedestrian safety for automobiles. The European Union has recently required many automobiles to be redesigned to increase pedestrian safety in accidents. It is possible that this is related to the fact that in France and Germany, drivers are strictly liable for pedestrian accidents.

422 J. LEGAL STUD. 205 (1973).
} 
could argue, perhaps, that the incentive created by fear of physical injury is already so great that adding or subtracting a pecuniary cost will not affect behavior. But Calabresi does not take this position. ${ }^{43}$

This is an example of the social optimum being defined under two different sets of constraints. Posner's Calabresi is concerned with the long-run effects of the liability rule and advocates making the producer strictly liable because in the long run it is likely that he can most cheaply reduce the cost of accidents. Posner, instead, focuses on the short run and notes the inefficiency of making the liability rule insensitive to the victim's negligence. To know which is more efficient overall, one must know whether the long-run efficiency of holding the manufacturer liable outweighs the shorter-run efficiency of inducing victims to take precautions.

The answer will also depend upon the availability and cost of substitutes. If there are relatively inexpensive means of making safer lawnmowers, holding manufacturers liable might induce a reduction in accident costs. On the other hand, if there are relatively inexpensive precautionary measures that a potential victim might take, then holding the manufacturer negligent might increase accident costs. $^{44}$ It is difficult to draw general conclusions about these issues. The answers will depend on many questions that are quite specific to the accident risks being evaluated, such as the availability of substitutes and the price elasticities of various activities. This suggests an empirical research agenda that has largely been ignored. ${ }^{45}$

It is also possible to examine how tort law has grappled with the issue of identifying the appropriate inputs to examine in determining liability. Doing so will suggest an analytic framework to organize the relevant questions. This is not a general, formal theory of which variables a court should include in any given test. Instead, I propose a useful analytic tool, a continuum from long to short run, and show how specific doctrines of tort law map onto this dimension.

${ }^{43} I d$. at $213-14$.

${ }^{44}$ Even if we determine that the long-run optimum involves care on the part of the manufacturer, it might still be efficient to place liability on the part of the victims if we think that manufacturers will not comply. If this second best situation occurs frequently enough, then inducing precautionary care may be efficient.

45 By focusing on identifying the cheapest-cost avoider, Guido Calabresi identified many of these questions. See Guido Calabresi, The Costs of AcCidents (1970). 


\section{ThE SHORT- TO LONG-RUN ANALYTICAL FRAMEWORK AND TORT DOCTRINE}

The tort system places different incentives on different ways of reducing accidents. ${ }^{46}$ In order to understand the interaction between the tort system and these different ways of affecting accident costs, one can organize different ways of affecting accident costs along a continuum from the short run to the long run using the moment the loss becomes irreversible as an endpoint for our analysis. The short run-long run continuum extends from the situation in which all of the variables are fixed to the situation in which all of the variables are alterable.

For example, possible remedial measures that can occur after the accident occurs will be at the short run end of this continuum. ${ }^{47}$ At this point, all or nearly all of the accident-affecting variables are fixed. The level of care at the time of the accident is near the short-run end of this continuum. In the example of the driver, this might be whether or not the driver was paying attention to his driving at the time of the accident. The number of times per minute the driver checked his rear-view mirror is a slightly longer-run means of affecting accident costs. Driving a different way to work or buying new tires or taking a safe driving course are still longer-run ways of affecting accident costs. Buying a different car or driving less are even longer-run ways of affecting accident costs. Giving up driving altogether would be still a longer-run means of affecting accident costs. Perhaps structuring society around public transport would be a still longer run means of affecting accident costs.

This same continuum can be applied to the pedestrian in much the same way. In the short run, the pedestrian could take more care by looking around herself more often. This is an example of an input she can change given that she is walking in a particular place at a particular time. In the longer run, she could walk a different way or at a different time of day. In the still longer run she could give up walking altogether, or develop reflexes that would help her leap out of a car's way.

Accident-relevant inputs controlled by other actors can also be organized along this continuum. So, for example, the decision by the municipality to build or not build a sidewalk will affect the chance of accidents in the long run. The frequency that police are assigned to the intersection would affect accident costs in the medium run. Similarly, the efficacy of a police officer that directed (or misdirected) traffic might affect accident costs in the short run.

\footnotetext{
${ }^{46}$ Dari-Mariacci, supra note 3 at 2. See supra note 35 and accompanying text.

${ }^{47}$ See Rose-Ackerman, supra note 15 at 38-39 (collecting cases on plaintiff's duty to mitigate harm in various legal contexts).
} 
The concept of a short run where most inputs are fixed and a long run where most inputs are variable is taken from microeconomics. ${ }^{48}$ As in the microeconomic context, the concepts are not perfectly correlated with actual time but rather with the actor's ability to vary inputs. This tends to roughly correlate with time - the longer the time horizon of the actor, the more feasible it is to vary inputs because the costs (including informational costs) of the change in inputs can be spread over a longer period.

The short to long run continuum is analytically useful because many of the tests and doctrines of tort law, including negligence, contributory negligence, last clear chance, assumption of risk, cheapest cost-avoider, the victim's duty to mitigate damages and certain varieties of strict liability, are applied by taking certain cost variables as given, and exogenous to the test, and some as variable and endogenous. Every application of a liability test therefore occurs with a particular combination of variables that are considered relevant. These combinations of relevant variables can be analyzed and compared by roughly mapping them onto the short to long run continuum. Doing so reveals ways in which the common law adjusts to the tension between optimization for the short and long run.

\section{A. The Learned Hand Negligence Test}

Tort law unevenly affects different methods of reducing accident costs by performing liability tests at different places on this continuum. The Hand negligence test, for example, is normally performed at a fairly short run level of analysis. The common understanding of negligence usually includes whether or not the driver was paying attention at the time of the accident but not generally whether the driver could have inexpensively taken a different and less hazardous route or whether the driver could have bought a safer car. These factors are usually taken as given, exogenous to the Learned Hand cost-benefit analysis. ${ }^{49}$

If the courts perform the Hand test in the short run, there will be no incentive for injurers (or victims) to supply the efficiently increased amount of safety in the medium and long run, except to the extent of their expected liability. ${ }^{50}$ For example, drivers generally have no reason to consider accident

${ }^{48}$ PAUl A. SAUMELSON AND William D. NORDHAUS, ECONOMICS 505-06 (1989).

${ }^{49}$ The doctrine that a party's negligence must be the proximate cause of an accident has been used to limit analysis to fairly short run accident causes, but proximate cause doctrine does not prevent analysis of longer-run causes. See Guido Calabresi, Concerning Cause and the Law of Torts: An Essay for Harry Kalven, Jr., 43 University of ChiCAGO LAW REVIEW 69 (1975) (emphasizing instrumental use of doctrines of cause), Mark F. Grady Proximate Cause and the Law of Negligence, 69 IOWA L. REV. 363 (1984); see also supra text accompanying notes 5- 24 (discussion of conceptual unity of causation, scope of negligence, and sequential actor literature).

${ }^{50} \mathrm{This}$ is a restatement of the oft-noted inadequacy of negligence to produce efficiency when 
costs they generate by choosing to drive to a place rather than to take the train. There is no reason a court could not, in theory, perform the Learned Hand costbenefit negligence test in the longer-run. The driver, for example, might be held liable because the court found that he could have taken the train instead of driving for less than the expected cost of accidents from driving minus the expected cost of accidents from taking the train.

Alternatively, the pedestrian the driver hit could be held contributorily or comparatively negligent because she could have walked in her quiet neighborhood instead of in a more distant busy street and the court could determine that the marginal benefit she received from walking by the busy road was outweighed by the added risk of accidents. This would be a longer-run understanding of negligence than typically used by the courts.

Legal doctrine sometimes reflects a longer-run understanding of negligence. The Restatement (Second) of Torts 1965, sec. 267 reads: "A negligent act may be one which involves an unreasonable risk of harm... although it is done with all possible care." For example, the Restatement mentions, "there are many mountain roads which may properly be regarded as dangerous no matter how careful ... the driver may be... There is an inescapable risk in driving down a narrow and ill-kept mountain road... particularly if ...snow and ice has rendered the road slippery.... Mere use of such a route... may be negligent unless the utility of the route is very great."

The courts do occasionally use a long-run Hand test in product design defect cases. ${ }^{51}$ Ironically, the analysis is often called strict liability, though the Hand marginal cost-benefit analysis is very similar. The courts weigh the costs and benefits of proceeding with a particular design compared to the costs and benefits of other possible designs and decide whether the benefits of the design that the firm used outweighed its costs. ${ }^{52}$ Similarly, strict liability in failure to

reduction in the activity level is necessary. Injurers will have some incentive to reduce accidents in the long run under a short run negligence test to the extent that they expect to be found negligent in the short run. So if there is uncertainty in either the negligence standard or whether the injurer can meet that standard, the injurer will have an incentive to reduce accidents in the long run as well as attempting to meet the shorter-run standard.

${ }^{51}$ See Guido Calabresi and Alvin Klevorick, Four Tests for Liability in Torts, 14 J. LEGAL. STUD. 585, 590. (1985). Calabresi and Klevorick differentiate this ex post products liability test from the ordinary ex ante negligence test by pointing out that the test occurs after the accident and does not look so much to the reasonableness of the injurer's behavior ex ante as to whether the injurer's behavior was correct in hindsight. While this distinction explains some of the unique character of the test for strict products liability, it does not fully explain the breadth of variables included in the products liability analysis. It would be possible to perform an ex post short-run test, for example. Suppose ex post scientific research uncovers the dangerousness of not checking the rear view mirror every 15 seconds. This knowledge might impact a short-run negligence test.

${ }^{52}$ In Camacho v. Honda Motor Co., 741 P.2d 1240 (Co. 1987), the Supreme Court of Colorado overturned a summary dismissal of a suit alleging that Honda could have inexpensively 
warn cases is predicated on a long run Learned Hand cost-benefit negligence test. The court asks whether the expected accident costs that could be reduced by a warning would exceed the cost of the warning. ${ }^{53}$

\section{B. Cheapest Cost-Avoider Test}

As an alternative to the negligence test, Calabresi and Hirschoff proposed the cheapest cost-avoider test both to explain the basis of strict liability and as a prescriptive method for economic efficiency. ${ }^{54}$ In a cheapest cost-avoider test, the court decides not whether the injurer should have taken a higher level of care, but whether the injurer was in the better position to reduce accident costs including both the costs of information and the costs of acting upon that information. Unlike the negligence test, a cheapest cost-avoider test (when used at all) is usually performed at a long run level of analysis.

Calabresi and Hirschoff introduce another dimension to a liability test. They compare the level of generality of the cheapest cost-avoider test to that of the negligence test. The level of generality refers to the number of exceptions that are permitted and the degree to which cases are looked at on a case-by-case basis rather then in terms of broad categories. They argue that the decision for strict liability for ultra-hazardous activities, for example, is made at a high level of generality and that it is unimportant that in a particular case the plaintiff could have avoided the accident more easily than the defendant. ${ }^{55}$

The concept of level of generality used by Calabresi and Hirschoff is conceptually distinct from short and long run. It is possible, for example, for

added crash bars to its motorcycles and thereby prevented the leg injuries of Camacho. In discussing the resemblance of the defect test to negligence the court explained:

Of course, whether a given product is reasonably safe and, therefore, not unreasonably dangerous, necessarily depends upon many circumstances. Any test, therefore, to determine whether a particular product is or is not actionable must consider several factors. While reference to "reasonable" or "unreasonable" standards introduces certain negligence concepts into an area designed to be free of these concepts, that difficulty is much less troublesome than are the problems inherent in attempting to avoid dealing with the competing interests involved in allocating the risk of loss in products liability actions.

$I d$. at 1245-46. Regardless of the jury's focus, or the court's labeling, the kind of test used in products defect cases is a Learned Hand cost-benefit analysis looking at the long-term ways in which a manufacturer could have reduced accident costs. See Greenman v. Yuba Power Products, 377 P.2d 897 (Cal. 1963) (Traynor, J) (noting that jury could reasonably have concluded that the manufacturer negligently constructed tool and that this was part of strict liability test).

${ }^{53}$ See, e.g., Cotton v. Buckeye Gas Prods. Co., 840 F.2d 935 (D.C. Cir. 1988).

${ }^{54}$ Guido Calabresi \& Jon T. Hirschoff, Toward a Test for Strict Liability in Torts, 81 YALE L.J. 1054 (1972).

${ }^{55}$ Calabresi \& Hirschoff, supra note 54 at 1067-68. 
courts to perform a short-run cheapest cost-avoider or negligence test, taking most issues as given, at a high level of generality. For example, a court might rule that all pedestrians are to be held strictly liable for their injuries and the damages they cause from hitting automobiles on the grounds that in general they are the shortrun cheapest cost-avoiders, or on the grounds that in general they are negligent. ${ }^{56}$ The pedestrian would not be allowed to prove that in this particular instance, she was not the cheapest cost-avoider or was not negligent if the test is done at a high level of generality.

Conversely, it would be possible to use a long-run cheapest cost-avoider test at a low-level of generality. Such a test would look on a case-by-case basis to see if a particular party was the long-run cheapest cost-avoider. A court performing such a test in the railroad example would ask whether the particular railroad being sued or the particular farmer suing would have been the cheapest cost-avoider in the long run. ${ }^{57}$ The court would ask whether it would have been cheaper for this particular railroad to build the tracks through the infertile desert instead of the arable plains or for this particular farmer to cultivate land away from the tracks. ${ }^{58}$ Such a specific test at such a long-run basis would likely require the courts to process huge amounts of information.

This information cost suggests an explanation for the general correlation among the level of generality and both the type of test and whether it looks primarily at the short or long run. Negligence tests in general are used at a low level of generality and in the short run. Courts have to learn an enormous amount about the possible range of precautions that the defendant could have taken, in order to decide whether or not the precautions they did take were justified. ${ }^{59}$ This requires a great deal of information. Courts economize by taking many things as given, and ignoring long-run precautions, such as activity levels. The test is generally performed on a case-by-case basis, analyzing the specific circumstances

\footnotetext{
${ }^{56}$ This is in conflict with most conventional moral notions of fault, but not dissimilar to holding the stupid person to the reasonable man standard. Vaughn v. Menlove, 3 Bing. N.C. 468, 132 Eng. Rep. 490 (1837). See Calabresi \& Hirschoff, supra note 54 at 1070 for discussion of a general negligence that places liability on a category rather than single injurers and victims.

${ }^{57}$ The information costs of such a test are likely to be very high. In general information costs are related to the level of generality of the test. They are likely to be very low at a high level of generality and much higher when the court has to find specific information about the parties.

${ }^{58}$ See Stephen G. Gilles, Rule-Based Negligence and the Regulation of Activity Levels, $21 \mathrm{~J}$. Legal. StUD. 319 (1992) Gilles uses a continuum that resembles Calabresi and Hirschoff's between general rules that the courts use and case-by-case determination.

59 Brown, supra note 8 at 333 (to apply negligence test courts must "ferret out complete information about the underlying technology of accident prevention"). Mark Grady has suggested that specific untaken precaution proposed as negligence by the plaintiff critically structures the court's inquiries and (presumably) allows the court to economize on information costs. Mark F. Grady, Untaken Precautions, 19 J. Legal StUD. 139 (1989); see also Mark F. Grady, A New Positive Economic Theory of Negligence, 92 YALE L.J. 799 (1983).
} 
of the accident. ${ }^{60}$ Because the court is determining whether the defendant's action were cost-justified, it makes sense to make the decision on a fairly specific level since it is necessary to use specific information in determining whether the action was negligent.

In comparison, cheapest cost-avoider tests are generally performed at a longer-run level and a higher level of generality. This test, when performed at a high level of generality, does not require the specific information that the negligence test does because it is comparative and does not hold the defendant's actions to an absolute standard. Thus it makes sense that information costs are kept low by making the decisions at a high level of generality. Because the test is so general, considering long-run factors is not prohibitively costly.

Strict liability for ultra-hazardous activity, for example, can be analyzed as a cheapest cost-avoider test in the long run at a high level of generality. ${ }^{61}$ Individuals likely to be injured by planes were largely unfamiliar with them and the pilots were more likely to be in a position to reduce the costs of accidents, in some cases by not flying at all. The decision to make flying an ultra-hazardous activity is made at a very general level of analysis. The activity is analyzed in general, and the specifics of the case are unimportant if flying is considered an ultra-hazardous activity. The fact that in a particular case the victim could have more cheaply avoided the loss is unimportant to the decision-maker, if the activity, analyzed as a whole, is one in which the injurers are more likely to be able to reduce costs more cheaply.

As noted above, it is theoretically possible to perform a long-run cheapest cost-avoider test at a low level of generality. In this context, such a test would look to whether in this particular accident the flier was the long run cheapest cost avoider and could have just have easily walked or taken up something instead of flying or whether the victim was the cheapest cost-avoider. The resemblance of these questions to questions of negligence points out the fact that a specific cheapest cost-avoider test has to ask many of the same questions that a negligence test would ask in order to determine who the cheapest cost-avoider is and thus undermine the information cost advantage of the cheapest cost-avoider test. ${ }^{62}$

It is also possible to perform a cheapest cost-avoider test in the very short run instead of the long run. For example, suppose we analyzed an automobile accident using a short-run cheapest cost-avoider test. The result of the test will depend on the familiar question of which variables we take as given. If we take the driver's purchase of a particularly dangerous automobile as a given, the

\footnotetext{
${ }^{60}$ Rules like negligence per se can make the test more general. See Gilles, supra note 35 at 322.

${ }^{61}$ Calabresi \& Hirschoff, supra note 54 at 1067.

${ }^{62}$ An early critic of Calabresi's advocacy of strict liability made this same point. Richard A Posner, Strict Liability: A Comment, 2 J. LeGAL STUD. 205, 215 (1973).
} 
cheapest cost-avoider might be the pedestrian. ${ }^{63}$ This example shows how the level of analysis will affect who will be liable. In the longer run the automobile driver might be the cheapest cost-avoider and it would therefore be more efficient to impose liability on her. In the still longer run, it is possible that the automobile manufacturers might be the cheapest cost-avoiders because they might have inexpensively prevented the automobile from going out of control in the first place. Thus, just as in the case of the negligence test, the level of analysis-which variables are included in the calculus-can determine the outcome of the cheapest cost-avoider test.

\section{Combining Tests}

Courts sometime combine different tests at different levels of analysis. So, for example, in the doctrines of contributory or comparative negligence, assumption of risk and last clear chance, a court makes an initial determination using either the negligence or a cheapest cost-avoider test in a longer-run setting and then performs another test, looking at shorter-run inputs to possibly alter the assessment of liability.

\section{Contributory Negligence}

Contributory negligence is a negligence test applied to the plaintiff that serves to bar recovery. As with conventional negligence, it can be applied at any point along the short- to long-run continuum, though it is often applied in the shorter term than the original defendant's negligence test. Given that the other injurer was negligent, could the victim have prevented the accident at a cost less than the expected cost of the accident $?^{64}$ For example, suppose the defendant was negligently driving without adequate brakes. The plaintiff negligently wanders into the edge of a road, a place where non-negligent cars do not drive, and is injured but is barred from recovery because of his negligence. This is an example of a court analyzing the plaintiff's negligence given that the defendant was already negligent. The action of the plaintiff would not have increased accident costs independently of the negligence of the defendant. ${ }^{65}$

\footnotetext{
${ }^{63}$ This is, of course, similar to the last clear chance doctrine. See infra at text accompanying note 74.

${ }^{64}$ In $\S 482$ (2) of the Restatement of Torts (1947) "(2) A plaintiff is barred from recovery for harm caused by the defendant's reckless disregard for the plaintiff's safety, if knowing of the defendant's reckless misconduct and the danger involved to him therein, the plaintiff recklessly exposes himself thereto."

${ }^{65}$ Grady calls this reaction-period negligence. Grady supra note 6 at 20.
} 
This definition of contributory negligence can theoretically erode incentives for the injurer to take care, ${ }^{66}$ because the injurer might know that the victim will be found contributorily negligent. For example, suppose it is cheaper for workers in a factory to purchase heavy protective clothing than to suffer the expected cost of accidents, given that the defendant is negligent. If the defendant's negligence is not taken as given, the cheapest way of avoiding costs is having the defendant buy safety machinery. Perversely, this might cause the injurer to behave as dangerously as possible in the expectation that the plaintiff will fail to take elaborate (but cost-effective) measures and be found contributorily negligent. $^{67}$

A somewhat different form of contributory negligence exists when the plaintiff's negligence increases accident costs independently of the action of the defendant. In this case, the court's contributory negligence test does not take the defendant's negligence as a given, but as independent of the plaintiff's possible negligence. If, in our example of the distracted pedestrian, the pedestrian ran out in the middle of the busy street, the court might find him contributorily negligent in a longer-run test than in the first case. In the first example, the pedestrian negligence depended upon taking the defendant's negligence as a given, exogenous to the negligence calculation. In the second case, the defendant's negligence does not have to be taken as given in order to determine that the plaintiff's action was negligent. The negligence was independent of the defendant's negligence. We can say that the defendant's negligence was endogenous to this contributory negligence test because the defendant's negligence was not taken as a given. ${ }^{68}$ This contributory negligence calculus does not depend on the defendant's negligence being assumed and exogenous to the contributory negligence calculation. This type of contributory negligence test is not necessarily any shorter-run than the defendant's negligence, ${ }^{69}$ and does not

\footnotetext{
${ }^{66}$ See Mark F. Grady, Common Law Control of Strategic Behavior: Railroad Sparks and the Farmer, 17 J. Legal STUD. 15 (1988) and Donald Wittman, Optimal Pricing of Sequential Inputs: Last Clear Chance, Mitigation of Damages, and Related Doctrines in the Law, 10 J. LEG. STUD. 65 (1981).

${ }^{67}$ Grady explains that courts reduce this sort of strategic behavior by "making each party's reaction-period obligations depend on the other party's mental state," by, for example, not permitting a defense of contributory negligence when the first negligence was deliberate. Grady supra note 6 at 22-23. But if a technology is somewhat new, the failure to provide it might not be seen to be deliberate. Similarly, some activity level choices may not be seen to be deliberate in this sense simply because they are taken as given.

${ }^{68}$ Grady calls this precaution-period negligence. In the precaution period, any party is permitted to assume that any other party is taking adequate care. Grady, supra note 6 at 20 .

${ }^{69}$ The continuum between short and long run is a continuum of including greater or fewer variables as endogenous in the liability test. The exact variables that are successively included as one moves from short to long run are not defined. Thus it is somewhat difficult to speak of a contributory negligence test as being on a shorter or longer term than the original negligence test.
} 
involve the same risk of strategic behavior, because it is defined independently of the actions of the injurer. As a practical matter, it may be difficult to distinguish victim precautionary measures that are economically efficient only given negligent behavior from victim precautionary measures that are independently efficient in many cases.

\section{Comparative Negligence}

Structurally, comparative negligence is similar to contributory negligence in that it is a second test that can be applied using any set of inputs as variable, although, like contributory negligence, it is often applied on a shorter-run basis than the original negligence test. Like contributory negligence also, comparative negligence can either be defined independently of the injurer's negligence or taking the injurer's negligence as a given. Comparative negligence avoids the discontinuity of contributory negligence-a regime in which one additional quanta of care by the victim is the difference between full recovery and no recovery. But this fact does not change the analysis or alter the way in which a court has to choose to include or exclude variables in the negligence analysis. ${ }^{70}$

So, for example, if a court, in applying the comparative negligence test, takes the frequent running of a spark-emitting train as a given, the court might find the farmer one hundred percent negligent for stacking his flammable crops near the tracks. On the other hand, if the court considers the frequency of the train running as part of the comparative negligence analysis, it might divide the negligence apportionment and find the railroad partially negligent. Whether the court uses comparative negligence or contributory negligence does not affect the fundamental tension between the long-run optimal outcome and the short-run optimal outcome and how that is reflected in the choice of variables considered by the court. ${ }^{71}$

\section{Assumption of the Risk}

The relevant variables are not the same so we cannot simply look to see which is more inclusive. Nevertheless one can make rough generalizations about which between two tests seems to include more variables as relevant.

${ }^{70}$ Historically, some legal economists have disfavored it. See e.g. LANDES \& POSNER, supra note 2 at 314-15 (criticizing comparative negligence as a "doctrine that impose[s] additional administrative costs on the legal system with no gain in allocative efficiency"); $i d$. at 316 (predicting that insurance rates will be slightly higher in comparative negligence states).

${ }^{71}$ But see Mark F. Grady, Efficient Negligence, 87 GEO. L.J. 397, 416-17 (1998) (suggesting that comparative negligence provides fewer incentives for strategic behavior than contributory negligence). 
The assumption of risk doctrine is traditionally viewed as a defense to strict liability or negligence. The defendant claims that the plaintiff assumed the risk of the activity that caused the injury. As Calabresi and Hirschoff observe, the courts can use a short-term fairly specific cheapest cost-avoider test to determine whether the plaintiff assumed the risk, "a kind of plaintiff's strict liability.,"72 This is an example of the courts performing in the long run either a cheapest costavoider or a negligence test, and then applying a cheapest cost-avoider test in the short run. This combination of tests allows the courts to define the optimal solution more precisely. Rather than being forced to hold every injurer liable in the broad class that is defined by the conventionally highly general long-run strict liability, the doctrine of assumption of risk allows the court to exclude a certain class of parties from recovery.

It would be possible to apply the assumption of risk doctrine at an either more or less specific level and at an either shorter- or longer-run level. At a more specific level, the test might look to the individual characteristics of the plaintiff to see if she was, for some idiosyncratic reason, not the cheapest cost-avoider despite her membership in the larger class that, in general, is the cheapest cost avoider. $^{73}$

\section{Last Clear Chance}

The last clear chance doctrine test is an additional test performed by the court that can alter the outcome of its judgment. It can render judgment to plaintiffs when they would otherwise be barred from recovery by contributory negligence. It is usually a negligence test applied at a very short-term level. Given the longer-term negligence of both the injurer and the victim, was the injurer negligent?

One court explained the doctrine as follows:

[T] he last clear chance rule presupposes: (1) That plaintiff has been negligent; (2) that, as a result of his negligence, he is in a position of danger, from which he cannot escape by the exercise of ordinary caution; (3) that defendant is aware of plaintiff's dangerous situation under such circumstances that he

\footnotetext{
${ }^{72}$ Calabresi \& Hirschoff, Toward a Test for Strict Liability in Torts, 81 YALE L. J. 1055, 1065 (1972).

${ }^{73}$ In Brown v. San Francisco Ball Club, Inc., 99 Cal . App.2d 484, 222 P.2d 19 (1950), a court ruled that a woman could not recover from the stadium owner for a baseball hitting her while she sat behind an unscreened section of the stadium when there was a screened section available, notwithstanding the fact that she knew little about baseball. This suggests the assumption of the risk test is performed at a somewhat general level; not every specific idiosyncrasy (in this case ignorance of baseball) is taken into account when determining if the plaintiff assumed the risk.
} 
realizes, or ought to realize, plaintiff's inability to escape therefrom; (4) that defendant then has a clear chance to avoid injuring plaintiff by exercise of ordinary care and fails to do so. ${ }^{74}$

This test, then, takes the given negligent actions of the plaintiff and the defendant as being outside the scope of its short-run negligence analysis. The test only looks to whether the defendant could have avoided injuring the plaintiff by being reasonable, given the prior negligence of the plaintiff. This is the very shortest-run negligence analysis, taking all of the circumstances of the accident as outside the negligence calculus.

To recapitulate, liability tests that courts use can be placed on two continuums: the specific to general continuum and the long- to short-run continuum. The level of generality is concerned with the size of category on which the liability decision is based and the degree to which the court looks at the idiosyncrasies of the particular actors. The location of a particular test on the short- to long-run continuum will depend on how many variables the court takes as given and how many it takes as variable when it performs the liability test.

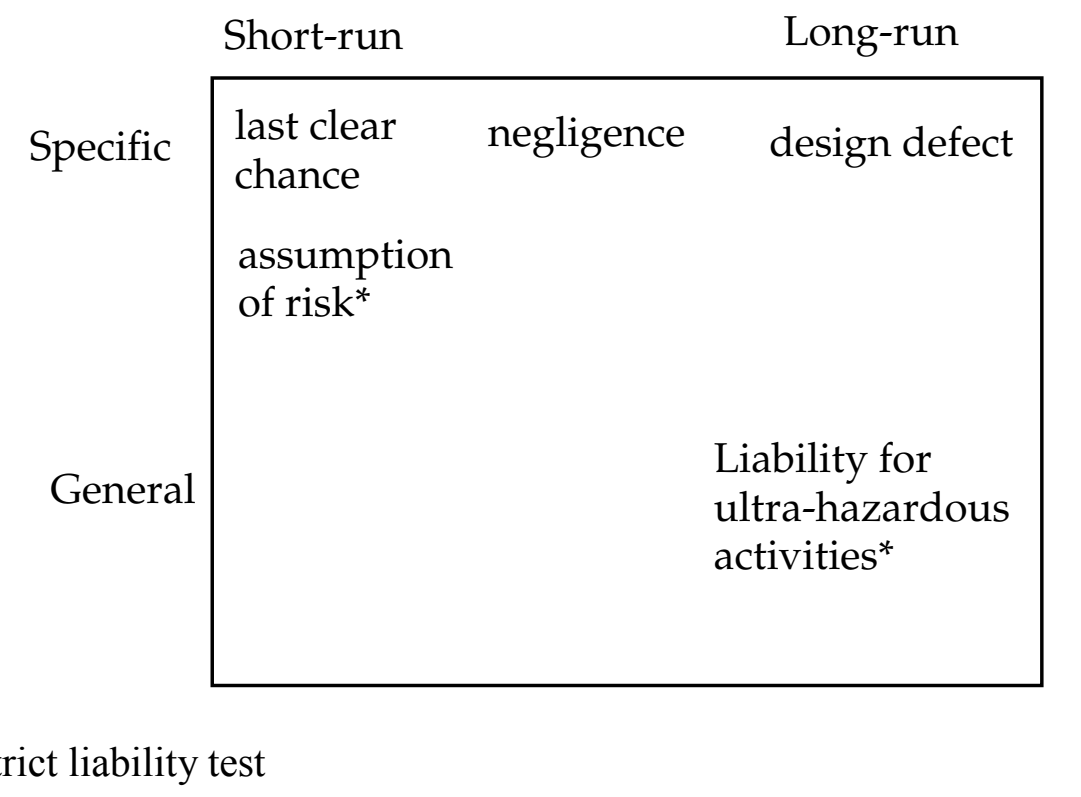

In practice, the courts combine the short- and long-run and general and specific negligence and cheapest cost-avoider tests in several ways. These include (1) a longer-run cheapest cost-avoider or negligence analysis coupled with a shorter-run cheapest cost-avoider analysis (strict liability with assumption of

${ }^{74}$ Bence v. Teddy's Taxi, 112 Cal. App. 636, 207 P. 128 (1931). 
risk); (2) a short-run negligence analysis coupled with an analysis of the plaintiff's short-run negligence and a second very short-term analysis of the defendant's negligence (conventional negligence with contributory negligence and last clear chance); (3) a short-run negligence test with a shorter-run cheapest cost-avoider test (conventional negligence with assumption of risk). ${ }^{75}$ These do not exhaust the possible combinations of tests. Courts could apply negligence or strict liability tests at other points on the short- to long-run continuum.

Given this universe of possible tests, how can one analyze when a particular test or combination of tests is efficient and which variables a court should include? Unfortunately, there is no general answer. ${ }^{76}$

Ceteris paribus, considering longer-run accident-reducing variables in liability tests will encourage certain categories of efficient accident-reducing behaviors that might otherwise be ignored. So, for example, the driver might consider driving less if the quantity of driving were included in the negligence test. But this must be measured against the difficulties that courts would have in measuring whether longer-run inputs were efficient. So, for example, it might be difficult for a court to determine whether it was efficient for the driver to be driving at a particular time or in a particular car. Including longer-run inputs in the test must also be weighed against undermining incentives for care for subsequent actors (both victims and others). Shorter-run tests (like last clear chance or contributory negligence) can be used to encourage subsequent actors to behave efficiently, but these doctrines will necessarily undermine incentives to undertake longer-run accident reducing measures to the extent they reduce expected liability.

\section{Regulation}

Regulation offers another means of affecting accident costs that can also be mapped onto the short- to long-run continuum. ${ }^{77}$ Regulations that prohibit the sale of cars without certain safety devices, for example, are a means by which long-run accident precautions can be affected. Prohibitions against the use of

\footnotetext{
${ }^{75}$ One can also apply any particular test with information available at the time the precaution level was chosen (ex ante), before the accident or during the trial (ex post). See Guido Calabresi \& Alan K. Klevorick . Four Tests for Liability in Torts, 14 J. LEGAL. STUD. 585 (1985).

${ }^{76}$ See Section II supra (discussing indeterminacy).

${ }^{77}$ A discussion of the advantages and disadvantages of regulation vs. tort liability is beyond the scope of this Article. See generally Steven Shavell, Economic Analysis of Accident Law (1987) at 277-286; Steven Shavell, Liability for Harm versus Regulation of Safety, 13 J. LEGAL StUD. 357 (1984); Donald Wittman, Prior Regulation versus Post Liability: the Choice between Input and Output Monitoring, 6 J. Legal STUD. 193 (1977); Guido Calabresi \& Douglas Melamed, Property Rules, Liability Rules, and Inalienability: One View of the Cathedral, 85 HARV. L. REV. 1089 (1972).
} 
tractors or bicycles on interstate freeways are regulations that affect shorter-run accident inputs.

A particular advantage of regulation that our analysis highlights is that regulation does not undermine liability incentives for subsequent actors to take care. Consider, for example, the issue of whether the choice of automobile should be included as a possible variable in determining whether a driver is negligent. As discussed above, the disadvantage of including such a variable in liability tests is that it might diminish incentives to take care for subsequent actors. If the government simply bans certain dangerous automobiles, there is no diminution of expected liability by subsequent actors. Similarly, if the government regulates the number of times the spark-emitting railroad passes by the farmer, the accidentaffecting behavior can be controlled without undermining incentives for subsequent actors - this case the farmer - to take proper care. This suggests an advantage to a legal regime that combines regulation ${ }^{78}$ with tort liability ${ }^{79}$ and a sensitivity to background social norms. ${ }^{80}$ The advantage in creating efficient incentives comes from the overlapping yet independent sources of suasion. ${ }^{81}$

\section{E. Prescriptive Implications}

In this section I used the concepts of short and long run as a descriptive analytical framework to describe the economic structure of tort law, and I discussed the way in which tort law doctrine and the related liability tests considered certain sets of accident inputs and ignored others (considered them as given). These tests and doctrines can be mapped onto the short- to long-run

${ }^{78}$ Of course, regulation also has substantial disadvantages. One is that it is potentially so heavy-handed-if the outside regulatory body miscalculates the costs it can ban certain activities altogether, whereas the tort system might merely inefficiently assign liability and not outright prohibit it. See GUIDO CALABRESI, COSTS OF ACCIDENTS 113-19 (1970). If the activity is actually efficient, then a firm should be able to bear the cost of the tort liability. This suggests that regulation should be restricted to those precautions for which there is a high degree of certainty of efficiency.

79 Another theoretical solution is decoupling liability by making both the injurer and the victim bear the cost of the harm. See A. Mitchell Polinsky \& Yeon-Koo Che, Decoupling Liability: Optimal Incentives for Care and Litigation, 22 Rand J. Econ. 562 (1991).

80 Social norms also serve as a valuable set of alternative constraints that can provide incentives for efficient behavior in the short, medium and long run, without undermining the incentives created by the tort system. For one particular view of the relationship between tort law and social norms, see Robert C. Ellickson, Order without LAw: How Neighbors SETtLe DISPUTES (1991). While Ellickson generally emphasizes the use of social norms in lieu of the tort system, I suggest that they can be complementary. A more comprehensive discussion of the relationship between tort law and social norms is outside the scope of this Article.

${ }^{81}$ In this respect, the doctrine of negligence per se, where an actor is held negligent for violating a regulation, undermines the independence of tort and regulation. 
continuum. This makes apparent the categories of inputs that a particular liability test or doctrine ignores and reveals the trade-offs between long-run and short-run optimality that a policymaker relying upon tort law faces in reducing accident costs.

This framework also has prescriptive implications. Different actors will have different abilities to affect short- and long-run accident inputs. For example, the municipality can design or redesign roads and sidewalks and spread the overall cost over decades. Other actors - for example, a tourist walking in a strange city-have fewer opportunities to affect the relevant long-run accident variables.

The varying time horizons of different actors can and should be accounted for in the liability tests. When determining whether a municipality is negligent for the design of an intersection, for example, the cost of the changes that would have avoided the accident should be spread over time. Conversely, a tourist should not be found negligent for driving a particular route in a strange city because the cost of identifying safer routes would be quite high. The tourist has limited ability to affect longer-run inputs. ${ }^{82}$ A similar analysis applies to information costs. A large landlord or city should take more long-run accident reducing measures than an individual actor since the fixed costs of learning about the efficient accident-reducing measures can be spread over a longer time horizon.

\section{CONCLUSION}

In this Article, I raise an issue that has only been tangentially addressed in the economic literature on tort law: which accident inputs should a court examine when determining liability and which should it take as given? Economic theory yields no a priori answer to this question. Without an answer to this question, the economic analysis of tort law yields indeterminate prescriptions. I propose an analytic framework - a continuum from long-run to short-run accident inputs to help understand the problem. Many conventional doctrines of tort law map onto this continuum, and it helps make clear the tradeoffs a court faces in choosing the scope of its tests.

If the economic analysis of tort law provides no one-size-fits-all answer to the question of which variables should be included in a liability test, what then should a court or a policymaker do to encourage efficient conduct? Unfortunately, no easy general answer appears possible.

Instead the answer will depend upon a number of empirical questions specific to the particular accident context. ${ }^{83}$ So, consider, for example, the

${ }^{82}$ Another way of putting this is that the time horizon of the actor will affect the cost of safer substitutes and the price elasticity of the dangerous activity.

${ }^{83}$ Gary T. Schwartz made a similar observation in a slightly different context. See Gary T. 
question of whether a court should consider the choice of automobile when determining whether or not the driver was negligent. What is the price elasticity of the demand for dangerous automobiles? Would added tort liability cause a shift away to safer substitutes? Would liability on the basis of auto selection lead municipalities or pedestrians to take fewer precautions? If so, how many more accidents would result? Are there other accident-affecting variables that the decision to include or exclude the choice of automobile would affect? While by no means trivial to answer, many of these questions do have empirical answers. As the legal academy grows empirically more sophisticated, these kinds of questions should receive increased attention. ${ }^{84}$

These types of questions - questions about the specific economic structure of an accident situation-should sound somewhat familiar. Guido Calabresi raised many very similar questions over thirty years ago in The Costs of Accidents. ${ }^{85}$ And while he was not considering the specific issue of accident variable inclusion in liability tests, his call for attention to the specific structure of the accident context provides useful guidance for our dilemma as well. He also stressed the need for careful analysis of possible substitutes in determining where liability should be allocated and the need for empirical testing. ${ }^{86}$

Yet his call for careful analysis of specific accident contexts and empirical testing has not received as much attention as it should. Since Calabresi wrote, the economic analysis of tort law has been dominated by general models with comparatively little attention paid to the specific accident-reduction technologies, or the economic structure (the price-elasticities and availability of substitutes) of

Schwartz, Reality in the Economic Analysis of Tort Law: Does Tort Law Really Deter? 42 UCLA L. REV. 377, 383 (1994) (noting difficulty in making generalizations about the efficacy of deterrence for all of tort law). Schwartz instead examines specific accident contexts to evaluate the empirical evidence of deterrence. See also Don Dewees \& Michael Trebilcock, The Efficacy of the Tort System and its Alternatives: A Review of Emprical Evidence, 30 OSGOODE HALL L.J. (1992).

${ }^{84}$ See John C. P. Goldberg, Twentieth-Century Tort Theory, 91 GEO. L.J. 513, 579 (2003) (noting the need to learn more about the "deterrent effects of tort law as well as innumerable other facts bearing on the tort system.").

${ }^{85}$ Guido CAlabresi, The Costs Of AcCidents (1970). See, e.g., id. at 140 ("The cost of reducing accident costs by reduction in or modification of a given activity will depend both on its market desirability (how much people want it and how many substitutes it has) and on the relation it bears (in some causal sense) to the accident costs under consideration. For example, although the costs of car-pedestrian accidents could probably be reduced substantially by reductions and modifications of pedestrian activity, such cost reduction might be too expensive if pedestrianism were viewed as a fixed activity, i.e. one without ready substitutes."); $i d$. at 155 ("In other words, the search for the cheapest avoider of accident costs is the search for that activity which has most readily available a substitute activity that is substantially safer. It is a search for that degree of alteration or reduction in activities which will bring about primary accident cost reduction most cheaply.")

${ }^{86}$ Id. at 157 ("[W] e will be able to test our choices empirically.") 
particular recurring accident situations. ${ }^{87}$ But, as I have tried to show, the general answers that the general models offer-e.g. the negligence test will result in the efficient level of precaution with or without a rule of contributory negligenceare indeterminate without a theory of which variables to include in the liability test. The kind of accident context-specific work, partly analytical and partly empirical, that Calabresi outlined in Costs is crucial to determining which variables should be included in liability tests in particular contexts and indeed which liability tests should be used.

The growing empirical literature provides important preliminary information for this enterprise, but much remains to be done. ${ }^{88}$ There is little consensus even on some basic questions. ${ }^{89}$ Most of the empirical literature evaluates specific reforms but does not attempt to take a mid-level analytical perspective on the recurring accident situation. And some questions will simply require careful extrapolations since the relevant data does not (yet) exist. For

87 There are important exceptions. See, e.g. Michelle Mello \& Troyen A. Brennan, Deterrence of Medical Errors: Theory and Evidence for Malpractice Reform, 80 TEX. L. REV. 1595 (2002) (analyzing deterrence of medical errors and proposing tort reforms to make increase deterrent effect); Michael J. MOORE \& W. KiP Viscusi, COMPENSATION MEChANiSMS FOR JOB RISKS 133 (1990); Elisabeth M. Landes, Insurance, Liability and Accidents: A Theoretical and Empirical Investigation of the Effect of No-Fault Accidents, 25 J.L. \& ECON. 49 (1982); Frank A. Sloan, Bridget A. Reilly, \& Christoph Schenzler, Tort Liability Versus Other Approaches for Deterring Careless Driving, 14 INT'L REV. L \& ECON. 53 (1994) (concluding, inter alia that dram shop liability reduces fatalities); Frank J. Chaloupka, Henry Saffer, and Michael Grossman, Alcohol-Control Policies and Motor-Vehicle Fatalities, 22 J. LEGAL STUD. 161 (1984); Aaron Edlin, Per-Mile Premiums for Auto Insurance (Working Paper No. 6934, Nat'l Bur. Econ. Res. 1999) (estimating effects of adopting per-mile automobile insurance premiums); see also RoseAckerman, supra note 15 at 45 (recognizing importance of empiricism in deciding appropriate institutional regime).

88 See sources cited supra note 87 and Alma Cohen \& Rajeev Dehejia, The Effect of Automobile Insurance and Accident Liability Laws on Traffic Fatalities, 47 J.L. \& ECON. 357 (2004); Aaron Edlin \& Pinar Karaca Mandic. The Accident Externality from Driving (Public Law Research Paper No. 130 Univ. California, Berkeley, 1999); J. David Cummins, Richard D. Phillips, \& Mary A. Weiss, The Incentive Effects of No-Fault Automobile Insurance, 44 J. L. \& ECON. 427 (2001); W. Kip Viscusi \& Michael Moore, Product Liability, Research and Development and Innovation, 101 J. PoL. ECON. 161 (1993) (attempting to measure effect of products liability on innovation); Benjamin Barton, Tort Reform, Innovation, and Playground Design, 58 FLA. L. REV. 265 (2006) (anecdotally examining effect of products liability on playground design).

${ }^{89}$ For example, there is apparently conflicting evidence on the effect of no-fault automobile insurance. Compare Elizabeth M. Landes, Insurance, Liability, and Accidents: A Theoretical and Empirical Investigation of the Effects of No-Fault Accidents, 25 J.L. \& ECON. 49 (concluding that no-fault increased accidents) and Marshall H. Medoff and Joseph P. Magaddino, An Empirical Analysis of No-Fault Insurance, 6 EvaluATION REV. 373 (1982) (same) with Paul Zador \& Adrian Lund, Re-Analysis of the Effects of No-Fault Auto Insurance on Fatal Crashes, 53 J. RISK \& INS. 226 (1986) (concluding that no-fault did not raise accident rates). 
example, no data exists for the effects of including a driver's choice of automobile in the negligence analysis, since no jurisdiction has included this input in a negligence test. Yet data exists on the comparative accident and fatality rates for various trucks and automobiles. From such information, the marginal risk to others of driving a dangerous versus not dangerous car might be calculated. Information on the price elasticities of dangerous cars would also be necessaryextending tort liability to price-inelastic drivers of dangerous cars would not much reduce the use of dangerous cars. The analysis will also will also require careful attention to the time-horizons of the relevant actors and the sequential nature of many accident inputs.

Was Judge Hand correct in analyzing the variables that he chose in Carroll Towing? The district court found the harbormaster and the tugboat jointly liable to owner of the barge that sank and did not hold the barge owner contributorily negligent for the absence of a bargee. ${ }^{90}$ Judge Hand partially reversed, holding that the tugboat and the harbormaster were jointly liable for the collision damages suffered when the barge broke free, but not for the subsequent sinking of the barge, which he concluded could have been prevented by the absent bargee.

Remarkably, Hand explained that the barge owner should have anticipated negligence on the part of tugs: "Certainly it was not beyond reasonable expectation that, with the inevitable haste and bustle, the work might not be done with adequate care." ${ }^{.91}$ By finding the barge owner contributorily negligent (in part), Hand undermined longer run incentives for the harbormaster and tugboat to avoid negligently rearranging barges. If the tugboat owners know that barge owners have a responsibility to make up for their negligence, they have less incentive to take proper care. Indeed, they have some incentive to be as flagrantly reckless as possible, in order to encourage barges to take extra care.

At first glance, it seems unlikely that it is efficient to require every barge to have a bargee aboard during the day in order to mitigate damages should a tugboat negligently disconnect its stays. The rule apparently allows the tugboats to shift a significant portion of the cost of care taking onto the barge owners. Why not simply require the tugboat to take "adequate care?"92

But perhaps wise Judge Hand knew that tugboats were already taking as much care as possible. Perhaps social norms or regulations were serving as alternative sanctions to keep the standard of care among tugboats efficiently high and that hiring inexpensive bargees to monitor the barges was a more efficient means of reducing accident costs. Absent knowledge of these contextual facts, the economic analysis of tort law provides no answer.

${ }^{90}$ Conners v. Pennsylvania R. Co et al., 66 F. Supp. 396, 398 (S. D. N. Y. 1946).

${ }^{91}$ United States v. Carroll Towing Co., 159 F.2d 169, 174 (1947).

${ }^{92} \mathrm{Id}$. 